\title{
DELIVERY AS "PHYSIOLOGICAL STRESS" AND ITS INFLUENCE ON LIVER ENZYMATIC SYSTEMS IN ASPHYXIAL NEWBORNS
}

\author{
Ingrid Brucknerováa , Marta Benedekováa, Karol Holomáñ ${ }^{b}$, Eva Bielikováb, Alena Kostrováb, \\ Eduard Ujházyc, Michal Dubovickýc
}

\author{
${ }^{a}{ }^{s t}$ Department of Pediatrics, Medical School, Comenius University \\ ${ }_{b} 2^{\text {nd }}$ Department of Gynecology - Obstetrics, Medical School, Comenius University \\ c Institute of Experimental Pharmacology, Slovak Academy of Sciences, Bratislava, Slovak Republic \\ e-mail:osmium@pobox.sk
}

Received: June 10, 2005; Accepted: September 25, 2005

Key words: Newborn/Oxidative stress/Aspartate aminotransferase/Alanine aminotransferase/Quotient DeRitis

\begin{abstract}
A new aspect on delivery as "physiological stress" provides the possibility for assessing its influence in asphyxial newborns. Asphyxia is characterized by hypoxic ischemic damage of organs with subsequent damage due to reoxygenation and reperfusion. The aim of the study was to compare the activity of liver enzymatic systems of healthy newborns with asphyxial newborns. Reference values of the AST on the $1^{\text {st }}$ day of life $0.80 \pm 0.12 \mu \mathrm{kat} / 1$ and on the $5^{\text {th }}$ day of life $0.78 \pm 0.11 \mu \mathrm{kat} / \mathrm{l}$, of the ALT on the $1^{\text {st }}$ day of life $0.29 \pm 0.04 \mu \mathrm{kat} / 1$ and on the $5^{\text {th }}$ day of life $0.54 \pm 0.21 \mu \mathrm{kat} / 1$ and of the quotient of DeRitis on the $1^{\text {st }}$ day of life $3.35 \pm 0.6$ and on the $5^{\text {th }}$ day of life $2.14 \pm 0.22$ were established. The quotient of DeRitis expresses better the influence of stress on healthy term newborns since isolated evaluation of liver enzymes and their dynamics, which is decreased on the $5^{\text {th }}$ day of life shows stabilization of the baby and improvement of liver cell function in comparison with the $1^{\text {st }}$ day of life. The authors found that delivery is considered to be a certain form of physiological stress.
\end{abstract}

\section{INTRODUCTION}

At the end of pregnancy the healthy term fetus is prepared for tolerance of the transitional physiological stress situation presented by delivery. The influence of stress on the fetus can be complicated by asphyxia as a risk factor ${ }^{1}$. It is one of the main causes of perinatal morbidity and mortality. Diagnosis of asphyxia is mostly established retrospectively, and thus its definition should be based on the given biochemical expression ${ }^{2}$. The starting point is establishment of physiological values of certain biochemical parameters, which help in the evaluation of asphyxia, ${ }^{3,4}$.

Aim of the study was to determine the activity of aspartate aminotransferase (AST), alanine aminotransferase (ALT), as well as to determine the quotient of DeRitis (ratio AST/ALT) in the healthy term newborns (HTN) on the $1^{\text {st }}$ and $5^{\text {th }}$ day of life and to compare them with asphyxial term newborns (ATN), as well as to find the enzymatic answer of the liver on the delivery in healthy newborns.

\section{SUBJECTS AND METHODS}

The study consisted of 39 newborns: 15 HTN, birth weight $3675 \pm 765 \mathrm{~g}$ (Department of Neonatology, $2^{\text {nd }}$ Dept. of Gynecology - Obstetrics) and 24 ATN, birth weight $2752 \pm 144.5 \mathrm{~g}$ ( $1^{\text {st }}$ Department of Pediatrics, Department of Pathological Newborns).

In the groups of HTN and ATN, samples of venous blood were taken on the $1^{\text {st }}$ and $5^{\text {th }}$ day of life for analysis of the plasma concentration of AST and ALT. AST and ALT were measured spectrophotometrically using the UV-method with pyridoxal-5-phosphate on a biochemical analyzer VITROS 250 (Ortho-Clinical Diagnostics, Rochester, USA). AST/ALT, quotient of DeRitis, was counted.

For statistical analysis, ANOVA by Fischer's post hoc test was used, $\mathrm{p} \leq 0.05$ was considered to be significant.

\section{RESULTS AND DISCUSSION}

Results of AST in HTN were on the $1^{\text {st }}$ day of life 0.80 $\pm 0.12 \mu \mathrm{kat} / 1$ and on the $5^{\text {th }}$ day of life $0.78 \pm 0.11 \mu \mathrm{kat} /$ 1. After reciprocal comparison with the values of ATN (ref. $^{5}$ ) on the $1^{\text {st }}$ day of life we found statistically important depression between both groups $\left({ }^{* *} p<0.01\right)$. In both groups we found also statistically important depression $(++p<0.01 ;+p<0.01)$ between values obtained on the $1^{\text {st }}$ and $5^{\text {th }}$ day of life (Fig. 1).

The values of ALT were in HTN $0.29 \pm 0.04 \mu \mathrm{kat} / 1$ on the $1^{\text {st }}$ day of life and $0.54 \pm 0.21 \mu \mathrm{kat} / 1$ on the $5^{\text {th }}$ day of life. After reciprocal comparison with the values of ATN (ref. $^{5}$ ) we did not find in the group of HTN a statistically 


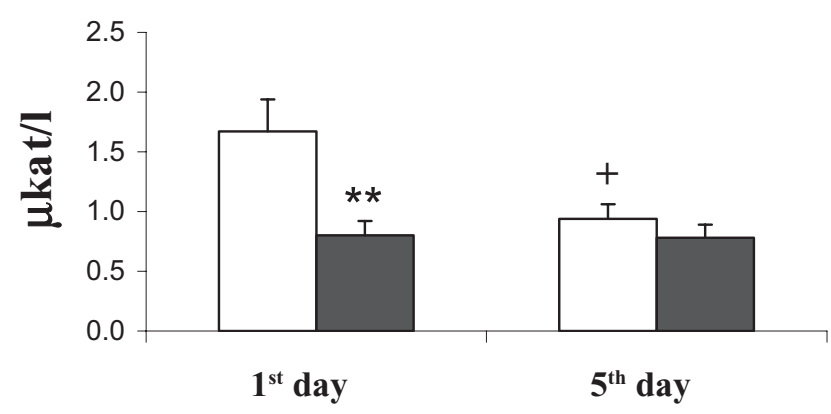

$\square$ asphyxial term newborns

healthy term newborns

Fig. 1. Comparison of AST values between asphyxial term $(n=24)$ and healthy term $(n=15)$ newborns on the $1^{\text {st }}$ and $5^{\text {th }}$ day of life. $+p<0.01-$ statistical significance in the group of asphyxial term newborns between the $1^{\text {st }}$ and $5^{\text {th }}$ day of life, ${ }^{* *}$ p $<0.01-$ statistical importance between both groups on the $1^{\text {st }}$ day of life

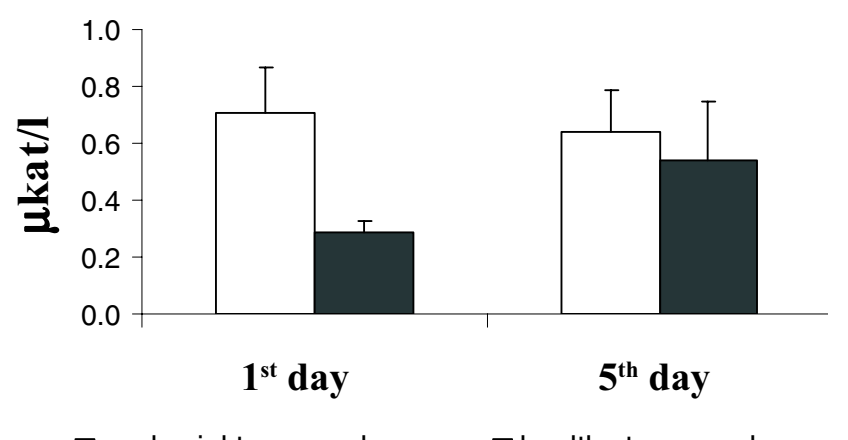

$\square$ asphyxial term newborns

healthy term newborns

Fig. 2. Comparison of ALT values between asphyxial term $(n=24)$ and healthy term $(n=15)$ newborns on the $1^{\text {st }}$ and $5^{\text {th }}$ day of life.

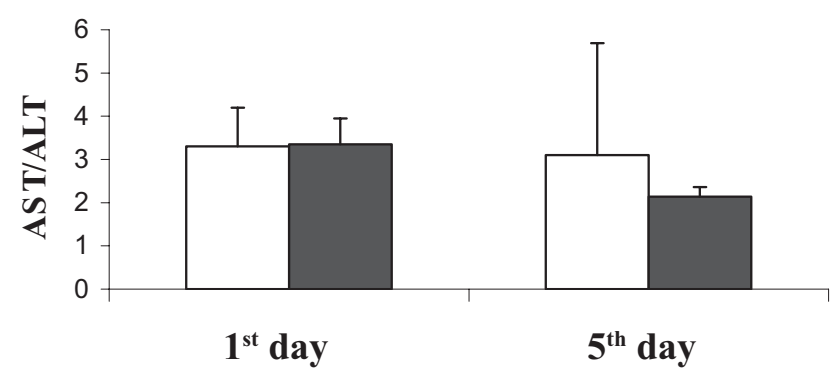

$\square$ asphyxial term newborns

healthy term newborns

Fig. 3. Comparison of AST/ALT values between asphyxial term $(n=24)$ and healthy term $(n=15)$ newborns on the $1^{\text {st }}$ and $5^{\text {th }}$ day of life. important change between values obtained on the $1^{\text {st }}$ and $5^{\text {th }}$ day of life (Fig. 2).

In the group of HTN, the values of the quotient DeRitis were $3.35 \pm 0.6$ on the $1^{\text {st }}$ day of life and 2.14 \pm 0.22 on the $5^{\text {th }}$ day of life. In all subjects the obtained values were greater than 1.0 (Fig. 3).

The obtained findings showed an elevation of AST values on the $1^{\text {st }}$ day of life in the group of ATN, which was statistically significant $(+\mathrm{p} \leq 0.05)$. This increase may be the consequence of hypoxic organ damage (liver, heart, muscles) and mainly of the liver parenchyma, which needs an adequate amount of oxygen, glucose and nutrients for its function ${ }^{3,4}$. On the $5^{\text {th }}$ day of life, we found a statistically significant depression of AST values in the group of ATN. A minimal, but not statistically significant depression was found in the group of HTN. We suppose that this depression in both groups of newborns is a reflection of stabilization of the babies and normalization of their liver functions (none of the babies had an infectious disease of the liver or of muscles).

Increased activity of ALT is a sensitive sign of impaired liver membrane, mostly in situations with decreased intake of energetic substrates into the cell ${ }^{6}$. On the $1^{\text {st }}$ day of life, the values of ALT in ATN are higher than in the control group. We did not confirm a statistically significant difference, but we presume that in comparison with the control group of HTN the asphyxia was so severe that insufficient intake of oxygen and energetic substrates may be supposed. The values of ALT on the $5^{\text {th }}$ day of life in ATN decreased mildly in comparison with HTN, where we found mildly increasing values. The decreasing of ALT values in ATN may have been influenced by better control of the whole amount of energetic substrates (proteins, fats, carbohydrates), since the patients were admitted to the intensive care unit. HTN were on rooming system and the source of energy was only the breastfeeding with various volumes of breast milk.

The liver is an organ with high energetic dynamics. On supposing that in dynamical systems increase of values with consequently periodical arrangement of some values happen earlier, then in a stress situation the increase of the quotient of DeRitis on the $1^{\text {st }}$ day of life is directly proportionate to its intensity ${ }^{5}$. Racek et al. ${ }^{6}$ considered the value above 1.0 (for adults patients) as a marker of increased membrane permeability of liver cells and of changes of mitochondrial membrane characteristics. There is a certain variability in the system.

In our group of subjects we compared the reaction of 2 groups of newborns. The group of asphyxial newborns was characterized by the presence of the asphyxial event. The control group consisted of HTN delivered spontaneously by head position and the delivery was for them a certain form of "physiological stress situation". The values of the quotient of DeRitis were in both groups of newborns above 1.0. The results of AST/ALT were on the $1^{\text {st }}$ day of life surprisingly on the same level in both groups, despite the fact that all ATN were resuscitated and the history of 9 cases showed loss of movement activity and that of 14 cases exhibited deceleration of heart sounds. 
The obtained physiological values of AST/ALT in HTN were on the $1^{\text {st }}$ day of life more than 3 times higher than in adult patients. On the $5^{\text {th }}$ day of life, ATN showed mildly decreasing values of AST/ALT. The variability of values in ATN was on the $5^{\text {th }}$ day of life greater than in HTN. We assume that the organism of term newborns has a greater tolerance and permits greater value dispersion.

Concluding, the values of the quotient of DeRitis express better the current condition of a newborn than does isolated evaluation of liver enzymes. The dynamics of numerical expression of quotient of the DeRitis (decrease) is pointing to stabilization of the patient and to improvement of liver function. Due to its feasibility, we recommend easy availability to investigate the activity of liver enzymes: AST, ALT and to calculate the quotient of DeRitis as a routine mathematical expression of asphyxia presented on the $1^{\text {st }}$ day of life as well as control of its dynamics.

In the future, further control and monitoring of the presence of asphyxia and support by antioxidant protection of the fetus/newborn is recommended, similarly as it is done in an animal experiment and considered necessary in cardiovascular surgery ${ }^{7-11}$.

\section{ACKNOWLEDGEMENT} 25 .

This study was supported by the grant VEGA 2/5052/

\section{REFERENCES}

1. Brucknerová I, Benedeková M. (2000) Asphyxia of the newborn - the ever topical problem. Biologia 55/Suppl 8, 23-6.

2. Štípek $\mathrm{S}$ et al. Antioxidants and free radicals in health and disease development. Prague: GRADA publishing, 2000.

3. Lackman GM, Tollner U. (1996) The predictive value of elevation in specific serum enzymes for subsequent development of hypoxicischemic encephalopathy or intraventricular hemorrhage in fullyterm and premature asphyxiated newborns. Neuropediatrics 26 , 192-8.

4. Lackman GM. (1996) Influence of neonatal idiopathic respiratory distress syndrome on serum enzyme activities in premature healthy and asphyxiated newborns. Am J Perinatol 13, 329-34.

5. Brucknerová I, Benedeková M, Pecháñ I, Franková E, Ujházy E, Dubovický M. (2005) Influence of oxidative stress on liver cell function on the $1^{\text {st }}$ and $5^{\text {th }}$ day of life in asphyxial newborns. Biologia, Bratislava, in press.

6. Racek J. et al. Clinical biochemistry. Prague: Karolinum, 1999.

7. Pecháń I, Holomáň M, Záhorec R, Rendeková V, Gabauer I. (1996) Antioxidant vitamins and phosphocreatine as protective agents in cardiac surgery. Biochemical parameters. Cor Europ 5, 69-73.

8. Holomáň M, Záhorec R, Rendeková V, Pecháň I. (1999) Vitamin E for skeletal muscle protection against reperfusion injury during elective revascularization surgery (biochemical and clinical assessment). Cor Vasa 41, 73-83.

9. Holomáň M, Pecháñ I. The protection of myocardium in cardiovascular surgery. Bratislava: ELÁN, 2002.

10. Brucknerová I, Benedeková M, Pecháń I, Franková E, Ujházy E, Dubovický M. (2004) Protection of newborn organism agains effect of oxidative stress. Cent Eur J Publ Health 12, Suppl, S18-20.

11. Navarová J, Ujházy E, Dubovický M, Mach M. (2004) Effect of melatonin on biochemical variables induced by phenytoin in organs of mother, fetuses and offsprings of rats. Cent Eur J Publ Health, Suppl 12, S67-9. 